\title{
PASSAGE THROUGH THE STRAIT OF TIRAN AND IN THE GULF OF AQABA
}

\author{
Leo Gross*
}

\section{INTRODUCTION}

The crisis in the Middle East which opened on May 18, 1967, with the request from the Government of the United Arab Republic to the Secretary-General of the United Nations to withdraw the United Nations Emergency Force (UNEF) "from the territory of the United Arab Republic and Gaza Strip,"1 and which was decisively aggravated by the announcement of the President of the Republic on May 22, I967 that "the United Arab Republic had decided to prevent Israeli ships and other ships carrying strategic cargoes to Israel, from passing through the mouth of the Gulf of Aqaba"2 was brought under control by the unanimous adoption on November 22, 1967 in the Security Council of Resolution 242. ${ }^{3}$ This resolution contains at least two principles which are directly relevant to the question here under consideration. According to the first, the Council affirmed that the establishment of a just and lasting peace in the Middle East requires the application of the principle:

Termination of all claims or states of belligerency and respect for and acknowledgment of the sovereignty, territorial integrity and political independence of every State in the area and their right to live in peace within secure and recognized boundaries free from threats of acts of force.

In the second principle the Council affirmed the necessity "[f]or guaranteeing freedom of navigation through international waterways in the area."

A settlement implementing these two principles will have to include the controversies which were aired once again in the Security Council prior to the outbreak of hostilities on June 5, 1967 and in the Fifth Emergency Special Session which followed their termination. These controversies related to the status in international law of the Gulf of Aqaba, the status of Israel as a coastal state in the Gulf, the right of innocent passage through the Strait of Tiran and, of course, the right claimed by the United Arab Republic to exercise belligerent rights in the Strait and Gulf. These problems will now be considered in that order.

- Dr. rer. pol. 1927, University of Vienna; S.J.D. I931, Harvard University. Professor of International Law and Organization, The Fletcher School of Law and Diplomacy, Tufts University. Member of the Board of Editors and Book Review Editor, American Journal of International Law.

${ }^{1}$ Special Report of the Secretary-General, U.N. Doc. A/6669, at I (1967).

${ }^{2}$ N.Y. Times, May 23, 1967 , at 1, col. 8.

s.C. Res. 242 ( 1967 ). See full text in Rosenne, in this symposium, pp. 44, 56. 
Status of Gulf of Aqaba in International Law

Since 1957 the Gulf has been claimed by various governments and writers as an historic gu:f or bay under exclusive Arab domination, more precisely the domination of the three Arab coastal states: the United Arab Republic, Jordan and Saudi Arabia. The position was first formulated by Saudi Arabia, ${ }^{4}$ and was restated by the representative of the United Arab Republic in the Security Council on May 29, 1967. What is involved is a mixed question of fact and law. By its configuration the Gulf of Aqaba has some similarity to the Gulf of Fonseca, which is usually relied upon as an analogue and precedent. It is about I00 miles long, the width varies from seven to fifteen miles, and it is connected with the Red Sea through the narrow Straits of Tiran, about nine miles wide. In the Fonseca case the Central American Court of Justice established three criteria in support of the historic character of the Gulf: first, immemorial possession, secondly, animus domini and thirdly, acquiescence by other nations. ${ }^{6}$ The Gulf of Aqaba meets none of these requirements. ${ }^{7}$ The Gulf has been said to have been Arab in character from 700 to 1517 . It was under Ottoman control from 1517 to 1918 , and since then it has been bounded by two littoral states and the British Mandate of Palestine, out of which Jordan and the state of Israel arose. 8 There is no evidence of an animus domini on the part of the Ottoman Empire. Even if it is assumed that all four present littoral states succeeded to the Ottoman Empire, they succeeded to no verifiable claim or right. ${ }^{9}$

What evidence there is points in the opposite direction. Up to I9x7 the Gulf of Aqaba seems to have been a backwater rather than an historic bay. Since that time British ships began to sail through the Gulf, joined by Scandinavian, German and others; ships of Arab states seem to have been rare users of the Gulf. ${ }^{10}$ In view of this, the proposition that "foreign Powers probably were not interested in navigation in the Gulf, since it apparently had no commercial importance to them"11 seems

\footnotetext{
"U.N. Doc. A/3575 (1957).

${ }^{5}$ U.N. Doc. S/PV.1343, at 31-42 (1967).

'Judgment of March 9, I917, The Republic of El Salvador v. The Republic of Nicaragua, ir As. J. INT'L L. 674, 705 (1917).

'But see Hammad, The Right of Passage in the Gulf of Aqaba, 15 Revue Ecyptienne de DRort INTERNATIONAL Ir8, 132 (1959), who finds that "in considering the legal status of the Gulf of Aqaba the analogy of the case of the Gulf of Fonseca is reasonable and logical." For a recent study of the subject, see H. Sultan, Le Probleme du Golfe d'Araba (Institut de Récherche et Études Arabologiques, Cairo, 1967$)$.

${ }^{8}$ Selak, A Consideration of the Legal Status of the Gulf of Aqaba, 52 AM. J. INT'2 L. 660, 692 (1958).

- Gross, The Geneva Conference on the Law of the Sea and the Right of Innocent Passage Through the Gulf of Aqaba, 53 Ass. J. INT'L L. 564, 569 (1959).

${ }^{10}$ Melamid, Legal Status of the Gulf of Aqaba, 53 AM. J. INT'x L. 412 (1959). Melamid concludes that his research "supports the view that navigation rights have definitely been established in the Gulf of Aqaba by nations other than the Arab states. Use of the Gulf by Arab states, particularly for pilgrim travel, followed only upon the pioneering efforts of other nations." Id. at 413 .

${ }^{11}$ Selak, supra note 8 , at 692 .
} 
without foundation. Whatever trade existed was "foreign, rather than local."12 Similarly, the view that because the Gulf is used for pilgrimages to Mecca it "enjoys a specific character that justifies the claim to be regarded as historical bay"13 is hardly persuasive. Moreover, some of the pilgrims seem to travel on non-Arab ships, and at least one of them, "the British ship Anchun, carrying Jordanian pilgrims from Aqaba to Jidda, was fired on by Egyptian shore batteries as a result of a misunderstanding."14

All these facts indicate that no juridical analogy can be drawn between the Gulf of Aqaba and the Gulf of Fonseca; there is no acceptable evidence of immemorial usage, of animus domini and of acquiescence. When Saudi Arabia formulated the claim to the historic character of the Gulf, the UNEF was stationed on the Strait of Tiran and Israel and other maritime nations passed freely through the Gulf.

In the debate in the General Assembly in 1957 only India seems to have taken the position that the Gulf was "an inland sea," but without any relevant supporting evidence. ${ }^{15}$

India also supported the claim of the United Arab Republic in $296 \%$. It justified it on several grounds, first that the Republic "is not a party to any agreement recognizing the Gulf of Aqaba as an international waterway or guaranteeing the freedom of passage to Israeli ships."18 This is obviously correct but the Republic is not a party to any agreement establishing the Gulf as an historic or closed bay. ${ }^{17}$ Furthermore, in view of Israel's coastline on the Gulf no such agreement could be arrived at and relied upon vis-à-vis Israel without her consent. ${ }^{18}$ The legal status of Israel in this context will be considered later.

The second Indian argument was that "there is no universally recognized rule of international law on freedom of navigation applicable to such bodies of water as Aqaba."19 This is correct but irrelevant. The principle of freedom of the seas applies to all waters which qualify as high seas or parts thereof. States which desire to exclude parts of the high seas from the regime of customary international law on historical or other grounds have the burden of the proof. As suggested earlier no

\footnotetext{
${ }^{12}$ Melamid, supra note Io, at $4 \mathrm{r3}$.

13 Hammad, stipra note 7, at 133 .

14 Selak, supra note 8, at 670 . Mr. Selak may have confused the facts. As stated in the House of Commons on July 6, 1955, by Mr. Nutting, Minister of State for Foreign Affairs, this ship was on the pilgrim run between Jedda and Aqaba but when fired upon and hit it was returning empty to Aqaba. 543 Part. Deb., H.C. (5th ser.) II34 (1955), quoted in 4 M. Whiteman, Digest of International LAW 478 (1965).

${ }^{16}$ Selak, supra note 8 , at 674 , points out that all the water areas cited by the Indian delegate are "indentations in the territory of one state only."

${ }^{16}$ U.N. Doc. A/PV.1530, at 81 (1967).

17 The absence of any agreement among the Arab littoral states was noted by Selak, supra note 8 , at 692 .

${ }^{18}$ Gross, supra note 9, at 570 .

${ }^{10}$ U.N. Doc. A/PV.1530, at 81 (r967).
} 
such evidence has been made available by the governments concerned or writers who support them. ${ }^{20}$

Moreover, there is strong evidence that the Arab coastal states as well as Israel have considered the Gulf to be part of the high seas; all of them proclaimed belts of territorial sea in the Gulf varying from three (Jordan) to six (Saudi Arabia, Egypt and Israel) miles. ${ }^{21}$ Claims to territorial sea imply that the Gulf is part of the high sea ${ }^{22}$ although there are exceptions on historical grounds as in the case of the Gulf of Fonseca. ${ }^{23}$ But no comparable exception has been established in favor of the Gulf of Aqaba before or after the establishment of the state of Israel.

In the debates in the General Assembly in February and March, 1957, a great number of Members have formally gone on record that the Gulf of Aqaba comprehends international waters and that there is a right of free and innocent passage in the Gulf. ${ }^{24}$ Similar views were expressed at the 1967 Fifth Emergency Special Session. ${ }^{25}$

The third Indian argument was that the status of the Gulf of Aqaba was "still a matter of controversy," and in support of this, the Indian delegate referred to a recent publication of the State Department,

the Digest of International Law, released by the Department of State in April r965 (vol. IV, p. 233) containing a letter from the Secretary of State dated I5 January rg.53, to the Attorney-General setting forth the views of the Department regarding the extent of territorial waters and the closing width of bays. On Aqaba, the letter states as follows: "The Gulf of Aqaba-the exact status of this body of water is still a matter open to controversy." I am sure there are many international lawyers in this august gathering and I make them a present of this quotation from an authoritative American textbook. ${ }^{26}$

This present, in spite of the generosity of the giver, should be accepted, if at all, with caution. It is true that there is a letter from the Secretary of State on the subject but it ends on page 232. The passage quoted by the Indian delegate is not from this letter but from a Memorandum prepared by Frank Boas, Attorney Adviser, Office of the Legal Adviser, Department of State, dated August $1957 .^{\text {27 }}$

After the passage quoted by the Indian delegate, Mr. Boas goes on to say that the Department of State in a recent statement published in The New York Times on June 24, 1957, declared that:

\footnotetext{
${ }^{20}$ No evidence is to be found in Murti, The Legal Status of the Gulf of Aqaba, 7 The INDian Journat of INTERnational LAW 201 ( 1967 ), who supports the Indian Government's viewpoint. Murti does not consider the arguments developed in my article cited supra note 9 .

${ }^{21}$ See Selak, supra note 8 , at 666 for relevant information.

$22 I d$. at 693 .

23 Gross, supra note 9, at 570 .

24 Gross, supra note 9, at 576, and Selak, supra note 8, at 671-75.

${ }^{25}$ Sec, e.g., U.N. Docs. A/PV.r531, at 29-30 (1967) (Belgium); A/PV.154r, at 13-15 (r967) (Peru); A/PV.1542, at $4 \mathrm{r}$ (1967) (Australia); id. at 58-60 (Costa Rica).

${ }^{36}$ U.N. Doc. A/PV.1530, at 81 (1967).

${ }^{27}$ See 4 M. Whiteman, supra note 14 , at 239.
} 
The United States position is that the Gulf of Aqaba comprehends international waters. That no nation has the right to prevent free and innocent passage in the Gulf and through the Straits giving access thereto. A denial of those waters to vessels of United States registry should be reported to the nearest United States diplomatic or consular offices. ${ }^{28}$

Still, it is true to say that a controversy exists although it is probably not sustained by any serious doubts as to the applicable law. The Arab claims, as one Egyptian writer put it, might not have arisen "except for the fact of Arab hostility toward Israel."20

\section{II}

\section{Status of Israel as a Coastal State in the Gulf of Aqaba}

It is part and parcel of the position of some governments and writers that Israel is not entitled to a stretch of the coast of the Gulf, that its presence there lacks legitimacy or is tainted with illegality. Thus the delegate of the United Arab Republic charged in the Security Council on May 29, 1967, that Israel's "presence lacks legitimate foundation."30 After referring to the resolutions of the Security Council adopted on July 15, 1948 and August 19, I948, the same delegate declared: "In view of these specific orders, Israel's possession of the coastal strip does not entitle it to any claim to sovereignty. This is in conformity with the well-etablished doctrine in international law that belligerent occupation cannot legally be converted into sovereignty over the occupied territory."31

These arguments suffer from a common but fatal defect. They confuse the deployment of military forces which may or may not be compatible with various resolutions of the Security Council or provisions in the relevant Armistice Agreements with exercise of sovereignty over territory. There may be armistice demarcation lines but there are also frontiers in the usual sense of the word, and while the territory of Israel may be determined by such lines it does not mean that the territory itself or parts of it are "armistice territories." No armistice lines were drawn along the coasts of Israel on the Mediterranean and the Gulf of Aqaba. Insofar as the coastline on the Gulf is concerned, it was provided in the 1947 Partition Plan Resolution of the General Assembly that the territory of the new state should extend to and include a stretch of coast which corresponded to the territory of the Mandate for Palestine. The Armistice Agreements with Egypt and Jordan define only the western and eastern demarcation lines or frontiers of this part of the state of Israel.

${ }^{28}$ Id. at 233. For material on the Gulf of Aqaba and Strait of Tiran, see id. at 465 . See also "The United States Reply to the Arab States Representations Concerning the Suez Canal and the Gulf of Aqaba: Statement Delivered to the Heads of Mission of the Arab States at Washington, June 27, I957," in Staff of Senate Coma. on Foreign Relations, goth Cong., ist Sess., a Select Chronorogt and Background Documents Relating to the Middle East il2-I5 (Comm. Print 1967).

${ }^{29}$ Hammad, supra note 7 , at 137 .

${ }^{30}$ U.N. Doc. S/PV.r343, at 31 (1967).

${ }^{31}$ Id. at $33-35$. 
Thus the General Armistice Agreement of February 24, I949 between Egypt and Israel provides in article II, paragraph 2: "No element of the land, sea or air military ... forces ... shall advance beyond or pass over for any purpose whatsoever the Armistice Demarcation Line set forth in Article VI of this Agreement . . . and elsewhere shall not violate the international frontier. ..."32

Article VI, paragraph I, of this Agreement also refers to "the Egyptian frontier" and article VIII, paragraph 2, refers three times to the Egypt-Palestine frontier. Article VII establishes in "certain sectors of the total area involved" a western and eastern front. This relates to the southern part of the territory of Israel, the western front being governed by the Armistice Agreement with Egypt whereas the eastern front comes under the regime of the Agreement with the "third party," namely, Jordan. Annex II to the Egyptian-Israel Armistice Agreement defines the demarcation between the two fronts. The eastern front is defined as "The area east of the line described in paragraph $a$ above, and from point 402 down to the southernmost tip of Palestine, by a straight line marking half the distance between the Egypt-Palestine and Transjordan-Palestine frontiers." ${ }^{33}$

Moreover, the Armistice Agreement explicitly recognizes Israeli possession of the territory by providing in article VII, paragraph 4 as follows: "In the area of the western front under Israeli control, Israeli defensive forces only, which shall be based on the settlement, may be maintained. All other Israeli forces shall be withdrawn from this area...."34 Clearly, a distinction is made between deployment of forces and control. Control remains even if forces are to be withdrawn.

The Jordan-Israel Armistice Agreement of April 3, I949 follows to some extent the earlier Agreement between Egypt and Israel. The demarcation lines are indicated on maps annexed to the Agreement and it is to be noted that there is no demarcation line along the coast on the Gulf of Aqaba. In the area concerned the lines run from north to south and not from east to west. Thus article V, paragraph I(d), provides: "In the sector from a point on the Dead Sea ... to the southernmost tip of Palestine, the Armistice Demarcation Line shall be determined by existing military positions ... and shall run from north to south as delineated on map $I$ in annex I to this Agreement."35

Furthermore, and quite explicitly, article VII stipulates: "The military forces of the Parties to this Agreement shall be limited to defensive forces only in the areas extending ten kilometres from each side of the Armistice Demarcation Lines, except where geographical considerations make this impractical, as at the southernmost tip of Palestine and the coastal strip." ${ }^{\text {"36 }}$

This coastal strip cannot be any other than that of Palestine under Israel control

\footnotetext{
${ }^{82}{ }_{4}$ U.N. SCOR, Spec, Supp. 3, at 2, U.N. Doc. S/1264/Rev.I (I949). (Emphasis added.)

ss Id. at Ir.

ss Id. at 5. (Emphasis added.)

${ }^{35}{ }_{4}$ U.N. SCOR, Spec. Supp. T, at 3-4, U.N. Doc. S/1302/Rev.x (1949).

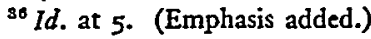


and part of its territory. Finally, mention may be made of Annex II which in paragraph II, section 4, defines the defensive forces in the "Sector Engeddi to Eylat" as three battalions each and various vehicles. ${ }^{37}$

A distinction between Armistice Demarcation Lines and international frontiers was made several times by the Secretary-General of the United Nations in his Special Report of May 18, 1967. Thus, he noted, "UNEF has been deployed in Gaza and Sinai for more than ten years for the purpose of maintaining quiet along the Armistice Demarcation Line and the International Frontier," and "All UNEF Observation Posts along the Armistice Demarcation Line and International Frontier were manned as usual."38

The state of Israel is not and was not an "armistice state" but a state with a territory delineated partly by armistice lines and partly by international frontiers. Certainly its maritime boundaries belong to the latter category. Thus there can be no question of the legitimacy in international law of its presence and its port on the Gulf of Aqaba. It certainly is not foreign territory conquered in violation of the Briand-Kellogg Pact or other treaties to which the doctrine of non-recognition may be applicable.

More specifically the delegate of the United Arab Republic referred to Security Council Resolution 89 (I950) as proof of the "illegal occupation" of the port of Elath on the Gulf of Aqaba. In that resolution the Council took note of the declaration of the government of Israel "that Israel armed forces will evacuate Bir Qattar pursuant to the 20 March $195^{\circ}$ decision of the Special Committee provided for in article $\mathrm{X}$, paragraph 4, of the Egyptian-Israel General Armistice Agreement .....39 The delegate went on "to clarify that the reference to Bir Qattar includes the vicinity of Om Rashrash which the Israelis called 'Elath' after their illegal occupation of the territory." $" 40$

Apart from the confusion between "occupation" and military deployment this clarification is somewhat misleading. The locality "Om Rashrash" on the Armistice map is on the Israeli side of the demarcation line of the Palestine-Transjordan frontier. There can be no question, therefore, of any "illegal occupation of the territory." Furthermore, the locality is in that sector of the area which has been called "eastern front" and is, therefore, within the legal scope of the Jordan-Israel Armistice Agreement. The distance between Bir Qattar and Om Rashrash may be close enough to permit the delegate to say that the former is in the vicinity of the latter, but this can be only geographic and not juridical vicinity. Inasmuch as the Security Council referred to the Egyptian-Israel General Armistice Agreement, therefore, juridically as well as geographically, $\mathrm{Bir}$ Qattar must be in the "western

\footnotetext{
${ }^{37}$ Id. at 10.

${ }^{38}$ U.N. Doc. A/6669, at 3 (1967). Further references will be found in id. at 7,9 .

${ }^{30}$ U.N. Doc. S/PV.1343, at 32 (x967).

${ }^{10} 1 d$.
} 
front" area. This Security Council Resolution cannot support any inference whatsoever with respect to Om Rashrash, which the Israelis called Elath.

The delegate of the United Arab Republic also charged that

The Israeli armed forces on to March 1949 usurped and occupied the village of Om Rashrash, along with a stretch of about five miles overlooking the Gulf of Aqaba .... This illegal act was perpetrated two weeks after the signing of the Egyptian-Israeli General Armistice Agreement on 24 February 1949. This action completely and drastically violated the letter and spirit of the Agreement ....41

This incident is the trump card in the reasoning designed to show that legally speaking Israel's territory does not comprise the coastal strip on the Gulf.42 It formed the subject of an investigation by the Truce Supervisory Organization and of a Report from the Acting Mediator of Palestine to the Secretary-General of the United Nations of March 22, 1949. This report deals with complaints made by Transjordan. It confirms that an Israel force reached "Umm Reshresh" and that "the eastern front, pending the conclusion of an armistice agreement with Transjordan, remains fully subject to the existing truce." ${ }^{33}$ The Acting Mediator, referring to the Aqaba area, stated: "It is clear on the evidence available to me as a result of the investigation by United Nations observers since 7 March that Israeli forces have effectively occupied this area since that date."

Referring to a couple of incidents, he reported: "I am quite convinced that, other than those at Aqaba, any positions established in this area either by Transjordan or by Israeli forces have all been established since the existing truce came into effect on I8 July 1948 . . and have, therefore, been established contrary to the terms of that truce." ${ }^{45}$

However, this incident occurred prior to the signing of the Jordan-Israeli Arristice Agreement on April 3, I949 and in an area covered by it. The charge of the delegate of the United Arab Republic that the deployment of the Israeli troops in the area of Om Rashrash was contrary to the Egyptian-Israeli General Armistice Agreement is without foundation. As the Acting Mediator pointed out, "Umm Reshresh" is in the eastern front area, therefore outside that Agreement. Moreover, it will be recalled, by virtue of the Jordan-Israeli Armistice Agreement that area along with the coastal strip fell within the territory of Israel. ${ }^{40}$ The demarcation line

\footnotetext{
"Id. He referred also to paragraphs I and 2 of Article IV of the Agreement.

12 After recounting the above incident, Hammad concludes: "In view of these prohibitions it is clear that Isracl's possession of the coastal strip, gained by the employment of the military instrument, is in the nature of a military occupation only, without lavful claim to sovereignty." Hammad, supra note 7, at 146.

${ }_{4}^{4}$ U.N. SCOR, Supp. March I949, at $46-47$, U.N. Doc. S/1295 \& Corr. I (1949).

Id. $2 t$ it.

${ }^{\mathrm{B}} \mathrm{Id}$. at $47-48$.

${ }^{-0}$ According to Selak, "in terms of the Armistice Agreements, a strong argument can be made for Israel's right to possession of its coastline on the Gulf of Aqaba. Just what is the legal nature of this possession, however, is somewhat unclear." Selak, supra note 8 , at $68 \mathrm{r}$.
} 
follows the old frontier between the Palestine Mandate and Transjordan, and ends on the shores of the Gulf. There would seem to be, therefore, juridically no reason to doubt Israel's right to this part of its territory. True enough, the Armistice Agreements did not pretend to draw political boundaries. But apart from the fact that they did not delineate all the boundaries of Israel-the coastlines being one exception ${ }^{47}$ and even if it is admitted that the armistice lines are normally provisional and subject to confirmation or revision in a peace settlement, Israel was admitted to the United Nations as a state with a territory. The coastline has been, with or without military deployment, part of its territory. As long as this continues to be so it will be legally one of the four riparian states on the Gulf of Aqaba and entitled to the use of its waters as well as ingress and egress through the Strait of Tiran. ${ }^{48}$

\section{III}

\section{State of War and Rights of Belligerency}

No passage in a textbook or treatise on international law has been more often cited in the Middle East crisis over the past few years than that in OppenheimLauterpacht that an armistice does not end the juridical state of war. ${ }^{49}$ Predictably it was quoted by the delegate of the United Arab Republic. After emphasizing the essentially military nature of the 1949 General Armistice Agreement, the continued violations thereof "which culminated in the cowardly attack on Sinai in 1956" he contended that "a state of overt war has been existing. Hence my Government has the legitimate right, in accordance with international law, to impose restrictions on navigation in the Strait of Tiran with respect to shipping to an enemy." 50

If there was nothing more to worry about than the question whether the imposition of the blockade was or was not in accordance with Oppenheim's views on armistices, there would not be much of a problem. However, the delegate claimed that the restrictions were "in accordance with international law," which is another matter. To begin with, if one takes Oppenheim's statement as authoritative then one would be bound to accept also as authoritative his statement that according

\footnotetext{
${ }^{47}$ Selak thinks it unlikely that the coastline on the Gulf is of a different legal nature than the land frontier without, however, elaborating the reasons for his doubts. Id. at 697 .

49 A line of reasoning that has not been explored and that cannot be explored here is whether the United Arab Republic and Jordan, which on May 15, 1948, illegally prevented the execution of the Partition Plan, can derive any advantages from their own action. Under the Plan the Jewish state was to comprise territory including the strip of the coast of the Gulf of Aqaba which has been under its sovereignty since 1948 .

"The full text is as follows: "Armistices or truces, in the wider sense of the term, are all agreements between belligerent forces for a temporary cessation of hostilities. They are in no wise to be compared with peace, and ought not to be called temporary peace, because the condition of war remains between the belligerents themselves, and between the belligerents and neutrals on all points, beyond the mere cessation of hostilities. In spite of such cessation the right of visit and search over neutral merchantmen therefore remains intact, as does likewise the right to capture neutral vessels attempting to break a blockade, and the right to seize contraband of war." 2 L. Oppenheim, International. LAw 546-47 (H. Lauterpacht ed. 1952).

${ }^{\circ 0}$ U.N. Doc. S/PV.1343, at 36-37 (1967).
} 
to article 46 of the Hague Regulations respecting the Laws and Customs of War on Land of 18939 and $x 907$ :

Any ser:ous violation of the armistice by one of the parties gives the other party the right of denouncing it, and even, in cases of urgency, of recommencing hostilities ..... ${ }^{51}$

Since the terms "serious violation" and "urgency" lack precise definition, the course to be taken is in practice left to the discretion of the injured party. ${ }^{62}$

Consequently, the war of June Ig67 would be a lawful war for the same reason as the restrictions imposed by the United Arab Republic were claimed to be lawful. However, this was not the view taken by the Republic at the time and since. In fact, it would seem that the Republic abandoned Oppenheim's international law on armistices which he formulated in the second edition published in 19r2, that is, even before World War $I_{,}^{53}$ and placed its case on the basis of the Charter of the United Nations, that is, the new international law. The armistice agreements must then be construed and applied in the framework of the Charter. This was done by the Security Council in its resolution of September I, I95I, and its competence to interpret and apply the armistice agreements cannot be doubted. ${ }^{54}$ This resolution declared generally that "since the armistice regime . . . is of a permanent character, neither party can reasonably assert that it is actively a belligerent or required to exercise the right of visit, search, and seizure for any legitimate purpose of selfdefence. ..."55 The Council made some additional findings of a general character and addressing itself to the specific complaint of Israel regarding Egypt's restrictions in the Suez Canal, called upon Egypt

tc terminate the restrictions on the passage of international commercial shipping and goods through the Suez Canal wherever bound and to cease all interference with such shipping beyond that essential to the safety of shipping in the Canal itself and to the observance of the international conventions in force. ${ }^{56}$

Egypt's non-compliance with this resolution is a matter of record. When Israel on January 28, 1954, complained to the Security Council about illegitimate interference with shipping passing to and from Israel through the Gulf of Aqaba, it was

\footnotetext{
"The Hague Convention and Declarations of 1899 and 1907, at 122 (J. Scott. ed. I915).

22 L. Oppenhem, International LAW 556 (H. Lauterpacht ed. 1952).

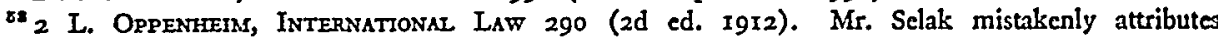
Oppenheim's statement on armistices to "the British jurist, Sir Hersch Lauterpacht." Selak, supra note 8, at $68 \mathrm{r}$.

${ }^{54}$ See Gross, Passage Through the Suez Canal of Israel-bound Cargo and Israel Ships, 5I Ax. J. J. INT'L L. 530, 545 (1957). Professor R. R. Baxter is of the opinion that this resolution can be regarded "as a legislative or law-creating act, rather than a judicial or law-declaring one," but "its burden is that the Armistice has placed special obligations upon the parties." R. BAXter, The Law of Internationaz WATERWAYS 230,235 ( 1964$)$.

${ }^{\text {EE }}$ S.C. Res. 95, para. 5 .

${ }^{80}$ Id., para. Io.
} 
not contested by Egypt that the I95I resolution applied to that waterway as well. ${ }^{67}$ Egypt on that occasion rejected again the I95I resolution as well as the proposed resolution on the Israeli complaint, which in any event failed of adoption as a permanent member of the Council, the Soviet Union, voted against it.

On May 30, 1967, replying to the representative of the United States, who described the first above-quoted passage from the 195I Security Council resolution $^{58}$ as "a fundamental principle," recalled that "two highly important factors affected the resolution":

First, four of the nine States that voted for the adoption of the resolution were parties to the dispute, and according to Article 27, paragraph 3, of the Charter, "a party to a dispute shall abstain from voting." It follows that, according to the provisions of the Charter, the resolution should not have been adopted. . . .

Secondly, the resolution was based on the assumption that for two and a half years no fighting had occurred between Egypt and the Israeli authorities. Again, for political aims, those members of the Council at that time flagrantly disregarded the numerous aggressive acts committed by the Israelis during those two and a half years, in spite of the fact that they were presented to the Council in detail by the representative of Egypt. However, even the assumption on which the resolution was based must have beer completely invalidated by the treacherous Israeli attack on Sinai in $1956 .^{60}$

The second argument is incorrect. The Council did not assume that for two and a half years no fighting had occurred, but stated merely as a factual proposition that the armistice regime "has been in existence" for that period of time, which is undeniable. As long as the armistice regime is in force, the conclusions of the Council rest on a firm juridical foundation. It would be open to the United Arab Republic to argue that the hostilities including those of $195^{6}$ had destroyed the armistice regime but this it did not do.

The first argument raises a matter of the internal procedure of the Council. In this case the objections of Egypt were heard by the members and not accepted. The Council is master of its own procedure and the September I, I95I resolution was declared adopted by the President. Of course, it is open to members to follow their own interpretation of the constitutional law of the United Nations but they do so at their own risk and peril. Certainly one member cannot impose its auto-interpretation on another member or on the Security Council.

The General Assembly in establishing UNEF and directing its deployment has neither explicitly rejected the Egyptian contentions regarding belligerency and incidental rights of visit, search and seizure nor has it explicitly adopted the opposite Israeli contentions. However, the stationing of UNEF along the Armistice Demarcation Line and in the Sharm El Sheikh area gave substantial satisfaction to the Israeli

\footnotetext{
${ }^{67}$ Gross, supra note 54, at 559-6I; R. BAXrER, supra note 54, at 21I-I2.

${ }^{58}$ See text accompanying note 55 supra.

${ }^{60}$ U.N. Doc. S/PV.1344, at 57 (1967).

${ }^{\circ 0}$ U.N. Doc. S/PV.1345, at 53-55, 56 (1967).
} 
request that there should be no interference with innocent passage and no assertion of belligerent rights in the Strait of Tiran. The General Assembly and the Secretary-General could do no less without violating the letter and spirit of the Security Council resolution of September I, r95I.

In this connection it is interesting to note that the withrawal of UNEF from the Strait of Tiran and the imposition of the blockade on May 22, 1967, were presented by the United Arab Republic as "a return to the conditions prevailing prior to 1956." ${ }^{\text {"61 }}$ The delegate of Pakistan, speaking at the Fifth Emergency Special Session of the General Assembly on June 22, 1967, stated the point more precisely as follows:

The action of the United Arab Republic did not create an entirely new situation; it merely restored the status quo ante and sought to liquidate a consequence of Israel's aggression in 1956 . Israel had enjoyed no right of passage through the Strait of Tiran before 1956, and this position had not aroused opposition on the part of most maritime Powers. ${ }^{62}$

The representative of the United Arab Republic, speaking in the Security Council on May 29, I967, referred to several statements made in connection with the 1957 discussion in the General Assembly and argued: "The 1956 aggression did not change the legal status of the Gulf of Aqaba and consequently did not affect the United Arab Republic's rights over its territorial waters."

The factual situation which obtained in the Strait and the Gulf prior to the stationing of the UNEF at Sharm El Sheikh must, of course, be distinguished from the juridical situation. The latter was expressed by most of the maritime powers in I957 and the above mentioned I95I resolution of the Security Council. The juridical point of view was also formulated by the United States authoritatively and formally with respect to both the pre-1956 conditions and the effect of the Security Council resolution as follows:

The attitude of the United States with respect to the right of free and innocent passage has not been altered by the events of last October and November. Those rights previously existed and are in no way based on the results of military action. It is, of course, clear that the enjoyment of rights of free and innocent passage is inconsistent with aggression. Thus, in the United States view Israel's right to free and innocent passage was dependent upon withdrawal of its forces behind the armistice lines in accordance with the United Nations resolutions. Once the situation envisaged by the General Armistice Agreements was restored, the principles of international law regarding free and innocent passage again became applicable to Israeli traffic in the Gulf of Aqaba. The Security Council resolution of September r, I95I, set forth the principle that a party to the armistice agreements could not assert that it was actively a belligerent. ${ }^{84}$

\footnotetext{
${ }^{01}$ Report by the Secretary-General, U.N. Doc. S/7906, at 3 (1967).

os U.N. Doc. A/PV.1531, at 47 (1967).

is.N. Doc. S/PV.r343, at 37 (1967).

of The United States Reply to the Arab States Representations Concerning the Suez Canal and the
} 
The establishment in 1957 of the right of free passage through the Strait and Gulf was correctly described as follows: "The legal situation which prevailed constituted a re-establishment of the régime which was established de jure by the resolution of the Security Council of September I, I95I, but not hitherto implemented."165

The United Arab Republic by re-imposing the closure of the Strait of Tiran and the Gulf of Aqaba, far from restoring the status juris quo ante, has reverted to the status injuriae.

The liquidation of UNEF operations and the resumption of belligerent practices by the United Arab Republic in May 1967 thus revived the old problem. The Secretary-General was obviously concerned about the revival of tensions in the area and recognized that "the situation in the Strait of Tiran represents a very serious potential threat to peace." He also urged all the parties to "forego belligerence."66 The keynote which was echoed by several Members in the discussions in the Security Council and the Assembly was formulated by President Lyndon B. Johnson on May 23, 1967, when he declared:

The purported closing of the Gulf of Aqaba to Israeli shipping has brought a new and very grave dimension to the crisis. The United States considers the Gulf to be an international waterway and feels that a blockade of Israeli shipping is illegal and potentially disastrous to the cause of peace. The right of free, innocent passage of the international waterway is a vital interest of the entire international community. ${ }^{67}$

The President formulated this as one of the five principles for peace on June I9, 3967: "The right of innocent maritime passage must be preserved for all nations."

The representative of the United States elaborated the President's statements in the Security Council. On May 24, 1967, he stated that the "conditions in the area have taken a still more menacing turn because of a threat to customary international rights which have been exercised for many years in the Gulf of Aqaba." ${ }^{* 09}$ On May 29, 1967, referring to the Secretary-General's report he said, "forgoing belligerence must mean forgoing any blockade of the Gulf of Aqaba," and "surely, stopping, searching and preventing the passage of ships through the Strait would clearly fall within the category of acts against which this [the Secretary-General's] appeal is directed." 70

Gulf of Aqaba: Statement Delivered to the Heads of Mission of the Arab States at Washington, June 27, 1957. Staff of the Senate Comam. on Foreign Relattons, gotm Cong., ist Sess., A Select Chronology aNd Background Docungents Rejating to the Middle East ir3 (Comm. Print 1967).

${ }^{\text {es }} \mathrm{R}$. Baxter, stipra note 54, at 215.

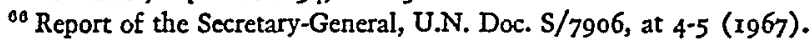

${ }^{07} 56$ DeP't STATE BuLL. 870-71 (I967).

${ }^{08} 57$ Dep't State Bull. 33 (1967).

${ }^{\circ 0}$ U.N. Doc. S/PV.1342, at $6(1967)$.

${ }^{70}$ U.N. Doc. S/PV.1343, at I6, I8-20 (1967). A request for compliance with the SecretaryGeneral's appeal was included in the United States draft resolution introduced on May 3I, 1967. See U.N. Doc. S/PV.1345, at 22 (I967). 
It is interesting to note that these statements do not refer to the Egyptian-Israeli General Armistice Agreement but seem to be based on broader grounds. The President simply considered the blockade "illegal," that is, presumably, contrary to international law. The representative of the United States considered "stopping, searching and preventing passage" as belligerent acts and presumably contrary to international law or the law of the Charter of the United Nations. The Security Council, in its resolution of September I, I95x, squarely based itself on the Armistice Agreement and the Constantinople Convention but not on the law of the United Nations. ${ }^{71}$ And yet it would have been logical and advantageous for the Security Council to adopt the latter position and to declare the Egyptian belligerent practices to be contrary not merely to the Armistice Agreement but above all contrary to the Charter of the United Nations. ${ }^{22}$

While Members of the United Nations do not appear to have expressed themselves on the subject of the compatibility of an active state of war, that is, of the exercise of belligerent acts, with the Charter, it is all the more remarkable that the resolution adopted by the Security Council on November 22, 1967, and referred to earlier in this paper, proceeds from the point of view of the Charter. It does so in the third preambular paragraph which reads: "Emphasizing further that all Member States in their acceptance of the Charter of the United Nations have undertaken a commitment to act in accordance with Article 2 of the Charter."73 Article 2 of the Charter includes the twin principles of refraining from the threat of or use of force and of settling international disputes "by peaceful means in such a manner that international peace and security, and justice are not endangered."

Furthermore, in operative paragraph $\mathrm{r}$, the Security Council "[a]ffirms that the fulfillment of Charter principles requires the establishment of a just and lasting peace in the Middle East which shall include the application of both the following principles."74 While the first principle relates to the "withdrawal of Israeli armed forces from territories occupied in the recent conflict" without any reference to the Armistice Agreements which figured prominently in the General Assembly resolutions with respect to the 1956 Middle East conflict, ${ }^{75}$ the second principle states: "Termination of all claims or states of belligerency .... . 78 The law of the Charter is the law common to all parties in the conflict and it was high time for the Security Council to declare that the state of belligerency which was claimed by the United Arab Republic to exist, and against which Israel always objected, must be terminated because of incompatibility with Charter principles. Whatever may be the outcome

\footnotetext{
${ }^{71}$ See Gross, supra note 54, at 564-68.

12 See also N. Feinberg, The Legality of a "State of War" after the Cessation of Hostiuties Under tae Charter of the Natjons aNd the Covenant of the League of Nations (Jerusalem, 196r). I3 S.C. Res. 242 (1967); 4 U.N. MonthII ChroN. I9 (Dec. r967). (Emphasis added.)

"Id. (Emphasis added.)

${ }^{76}$ Resolutions adopted by the General Assembly during its First Emergency Special Session from November I to 10, I956, U.N. GAOR (Emer. Spec. Sess. I), Supp. I, U.N. Doc. A/3354 (1956).

${ }^{70}$ S.C. Res. 242, supra riote 73.
} 
of negotiations between the parties, this declaration in itself is a substantial gain for the United Nations. ${ }^{77}$

\section{IV}

Freedom of Passage through the Strait of Tiran and in the Gulf of Aqaba

It has been shown that the claim to exclusive control of the Gulf of Aqaba on historic or other grounds was without merit. It has also been demonstrated that the territory of Israel includes a coast on the Gulf. There remains to be considered the question of passage through the Strait and the Gulf.

One problem can be eliminated. No government has contested the proposition that the entrance to the Gulf "is situated in the joint territorial waters of Saudi Arabia and the United Arab Republic. Due to navigational hazards the only navigable route to the Gulf runs less than one mile from the Sinai Peninsula. Hence it crosses our undisputed territorial waters."78 These are undisputed facts. As regards passage through the Strait of Tiran, it might be well to begin with the position of Egypt. On February Ir, 1957, the Secretary of State of the United States handed the Israeli Ambassador an aide mémoire in which he stated: "[T] Uhe United States believes that the Gulf comprehends international waters and that no nation has the right to prevent free and innocent passage in the Gulf and through the Straits giving access thereto.".79 $\mathrm{He}$ went on to say:

The United States recalls that on January 28, x950, the Egyptian Ministry of Foreign Affairs informed the United States that the Egyptian occupation of the two islands of Tiran and Senafir at the entrance of the Gulf of Aqaba was only to protect the islands themselves against possible damage or violation and that "this occupation being in no way conceived in a spirit of obstructing in any way innocent passage through the stretch of water separating these two islands from the Egyptian coast of Sinai, it follows that this passage, the only practicable one, will remain free as in the past, in conformity with international practice and recognized principles of the law of nations." 80

Thus by its own admission, Egypt considered the Strait of Tiran as open to passage and consequently recognized the right of passage in the Gulf. Clearly, were Egypt or now the United Arab Republic or Saudi Arabia actively involved in a war, they could deny passage to the ships of their opponent. But apart from this, there is no right to deny or obstruct passage. When the Government of Egypt in I955 issued instructions requiring prior notice from ships, the United States Government maintained its position that "no nation has the right to prevent free

\footnotetext{
${ }^{77}$ It may be noted that none of the three draft resolutions before the Security Council in' November I967 referred to the armistice agreements or armistice lines. 4 U.N. MoNTHLy ChroN. 8-9 (Dec. xg67).

${ }^{78}$ Mr. El Kony (U.A.R.), U.N. Doc. S/PV.1343, at 31 (Ig67). Mr. EI Kony gives the length of the Gulf as being about 96 miles and its widest breadth as less than 15 miles.

${ }_{79} 4 \mathrm{M}$. WhitexsN, supre note 14 , at 466 .

${ }^{80} I d$.
} 
and innocent passage in the Gulf and through the Straits giving access thereto."81 The British Government in 1955 "never recognized the legality of the Egyptian blockade cither of the Canal [Suez] or other waters, such as the Gulf of Aqaba, leading to Israeli ports," 82 and made no formal agreement with Egypt "about shipping proceeding to the Gulf of Aqaba," but rather it "adopted a de facto arrangement" while maintaining its legal position. ${ }^{83}$

At that period only the alleged existence of a state of war with Israel seemed to motivate Egypt to deny passage through the Strait.

In connection with the liquidation of the Middle East crisis in 1956-57, a good deal of attention in the General Assembly was focused on Israel's grievances with respect to the passage through the Strait of Tiran and in the Gulf of Aqaba. Fourteen Members, including those with the greatest interests in maritime freedom, expressed themselves in one form or another in favor of freedom of innocent passage through the Strait and in the Gulf. ${ }^{84}$ As indicated earlier, the deployment of UNEF in the area of the Strait was designed to and in fact did, ensure freedom of passage as long as it lasted but the General Assembly did not adopt a formal resolution on the subject.

However, shortly thereafter at the $195^{8}$ Geneva Conference on the Law of the Sea, the question was formally settled. ${ }^{85}$ The claim to exclusive control of the Gulf of Aqaba by the three littoral Arab states which was reiterated at the Conference found no support. On the contrary, it was generally taken for granted that there were four littoral states, including Israel. Nor was there any concern with the allegation that Israel had no legal right to its share of the coast. Whatever the status of the Gulf may have been prior to the establishment of Israel, it could not be regarded as a historic bay after establishment of the new state. ${ }^{80}$

The Conference boldly tackled the issues raised by the conflict between Egypt, Israel and the rest of the maritime community, which so far the International Law Commission and the General Assembly have avoided. In full awareness of these issues the Conference by a vote of $6_{5}$ for, I against and I abstention, ${ }^{87}$ adopted article r6 of the Convention on the Territorial Sea and the Contiguous Zone. ${ }^{88}$ The first

${ }^{81}$ Id. at 469 .

82543 PARL. Deb., H.L. (5th ser.) II35 (1955), quoted in 4 M. Whiteman, supra note I4, at 478.

82546 PARL. DEB., H.C. (5th ser.) 2288 (1955), quoted in 4 M. Whiteman, supra note $x_{4}$, at 480.

84 Gross, supra note 9, at 576-78.

85 "The seeming general consensus indicated by this debate [in the General Assembly] in favor of preserving a right of access to straits free of the arbitrary competence of the coastal state nevertheless found impressive confirmation shortly in the outcome of the 1958 Conference on the Law of the Sea." M. McDougal \& W. Burke, The Public Order of the Oceans 210-11 (1962).

80 "It would no doubt be argued . . . that even if the claim to historic rights were justificd the emergence of a new state bordering on the gulf altered the scope of authority normally associated with historic waters." Id. at 444. A similar change occurred in the Black Sea when Russia established itsclf on its shores. See Selak, supra note 8, at 693 .

${ }^{87}$ U.N. Conference on the Law of the Sea, Official Records, Vol. II, Plenary Meetings, at 65, para. 3 (1958).

${ }^{88}$ U.N. Doc. A/Conf. $13 /$ L.52 (1958). 
paragraph of this article accords to the coastal state the right to "take the necessary steps in its territorial sea to prevent passage which is not innocent," the second paragraph deals with control over ships proceeding to internal waters, the third paragraph permits temporary suspension of innocent passage "if such suspension is essential for the protection of its security," and finally paragraph four, which may be called the Aqaba article, reads as follows: "There shall be no suspension of the innocent passage of foreign ships through straits which are used for international navigation between one part of the high seas and another part of the high seas or the territorial sea of a foreign State."

In addition this Convention, which entered into force on September 10, 1964, and had been ratified by more than thirty states, including the United States, the United Kingdom, the Soviet Union, and France, lays down rules concerning innocent passage (articles $\mathrm{I}_{4}$ and 15 ) and the permissible laws and regulations applicable to foreign ships exercising the right of innocent passage. Such law and regulations must conform to the articles of the Convention and "other rules of international law" (article I7). ${ }^{89}$

The Conference made some changes in the relevant draft articles of the International Law Commission and "all the changes ... were clearly in the direction of promoting more inclusive use of straits and of restricting the authority of coastal states." The Conference deleted the word "normally"-the deletion was proposed by the United States-from the Commission's draft, ${ }^{91}$ on the ground that the word was not used by the International Court of Justice in its Judgment in the Corfu Channel case." The effect of the deletion is "to assure passage through straits which were actually used and to avoid friction over the concept of normal use."r3

The other important change related to the Commission's words "between two parts of the high seas" which qualified the word "straits." This was of particular importance with respect to the Gulf of Aqaba. Although in the view of some governments, notably of the United States, the Gulf was considered to comprehend international waters, this could be contested by others, and the argument became a casualty when Egypt and Saudi Arabia extended their territorial sea from six to twelve miles. The greatest width of the Gulf being between fifteen and seventeen miles, there is no room left for international waters. The point was made by several governments at the Conference that the essential aspect of the traditional principle of freedom of navigation was for ships to enter the port of destination and to have

\footnotetext{
${ }^{80}$ Concerning these provisions, see Gross, supra note 9, at 580-92, and M. MCDougal \& W. BuRkE, supra note 85 , at $174-304$.

${ }^{80}$ M. McDougar \& W. Burke, supra note 85 , at 211 .

${ }^{01}$ This draft was as follows: "There must be no suspension of the innocent passage of foreign vessels through straits normally used for international navigation between two parts of the high seas." Io U.N. GAOR, Supp. 9, at 20, U.N. Doc. A/2934 (1955).

22 [1949] I.C.J. 4. See also Gross, supra note 9, at 586.

${ }^{98}$ M. McDovgal \& W. BurRe, supra note 85, at 212.
} 
the right, for this purpose, to pass through the territorial sea ${ }^{94}$ This point was met by changing the words in the Commission's draft to read "between one part of the high seas and another part of the high seas or the territorial sea of another State." In this manner passage in the Gulf of Aqaba was secured. The principle of freedom of navigation was spelled out and placed on a more secure basis. By prohibiting suspension of innocent passage through straits, the Conference rejected decisively the competence of the coastal state "to control the strait as a means of projecting its influence for purposes of special national policy, not necessarily reflecting common interest." ${ }^{\text {95 }}$

The relevance of article 16 , paragraph 4 , of the 1958 Convention on the Territorial Sea for the controversy over the Strait of Tiran and the Gulf of Aqaba was contested in the Security Council and in the General Assembly in the debates in 1967.

In arguing the illegality of the blockade measures announced by the United Arab Republic, the representative of the United States referred to article 16, para. 4, of the $195^{8}$ Convention as evidence of international law. He described the status quo which existed from 1957 to 1967 as being "in accordance with international law." "Such law, indeed," he said, "has been expressed in the 1958 Convention on the Territorial Sea and the Contiguous Zone, to which many nations are parties."100

The representative of the United Arab Republic did not deny that the rule laid down in article 16 , paragraph 4, was declaratory of customary international law but contended that the Convention was inapplicable "to our case" because it lacked any reference "to the consequences of armed conflict." He supported his view by quoting from the report of the International Law Commission the sentence: "The draft regulates the law of the sea in time of peace only. ${ }^{97}$

This is, of course, correct but the relevant point is that the $195^{8}$ Conference did not adopt the Commission's proposal. Thus, quite deliberately, the Convention was intended to apply generally without reference to states of war and peace. But, as has been pointed out, the Convention, within limits, respects the security interests of the coastal states and in case of actual armed conflict the necessary consequences would have to be drawn. In this case, however, the existence of a state of war which would justify appropriate measures by the coastal state has not been recognized and its seems unnecessary to go over the same ground again.

Another argument against article 16, paragraph 4, is that it is a "new rule." The

\footnotetext{
'Gross, supra note 9, at 587-89.

${ }^{95}$ M. McDougal \& W. Burke, supra note 85 , at 189 . These authors also note that "[i]t is evident that there has been a fairly strong tendency over the past century to restrict the competence of coastal states over straits." Id. at 213.

${ }^{\circ 0}$ U.N. Doc. S/PV.r343, at I6-I7 (1967).

${ }^{\circ 7}$ U.N. Doc. S/PV.1344, at 47 (1967).

${ }^{98}$ See the speech of the representative of the Sudan, U.N. Doc. A/PV.r530, at 28 (1967); Murti, supra note 20, at 203. Concerning the pro-Arab position of the Indian Government, cf. Kozicti, Indian Policy Toward the Middle East, I I ORBIs 786 ( 1967 ).
} 
source of this is an article on the $195^{8}$ Conference by Arthur $\mathrm{H}$. Dean, who was head of the American delegation, in which he said with reference to this clause: "The Geneva Conference thus, in a politically charged area, achieved agreement sufficient to write a new and beneficent rule into international law."99

There is room for argument whether article 16 , paragraph 4 , creates a new rule which would be binding on the contracting states only or whether it merely specifies or particularizes a rule which is deemed implicit in customary international law, that is, the general principle of freedom of the seas and navigation. At the Conference itself there was substantial evidence that some delegates merely desired to make explicit the right of ships to sail from port to port through international waterways, this right being implicit in the general principle. ${ }^{100}$ In this sense there is nothing new in article 16 , paragraph 4 .

What is undeniably true, however, is that the rule is new in the sense that it differs in important respects, as indicated earlier, from the draft submitted by the International Law Commission. This is indeed the interpretation of Mr. Dean as appears from this clarification:

In making this statement I was thinking mainly in terms of fact that the question of innocent passage through straits between one part of the high seas and the territorial sea of a foreign state had not been covered by the decision of the International Court in the Corfu Channel case or in the draft articles prepared by the International Law Commission. I did not intend to pass upon the question of whether or not this rule represented a codification of customary international law. ${ }^{101}$

In the present submission the rule does represent a codification of customary international law although it could also be argued that it contains an element of progressive development of the law. The very substantial vote in favor of the rule at the Conference must also be considered as an expression of the Conference in favor of free and innocent passage through international waterways. That the Conference was also aware that in article I6, paragraph 4 , it "adopted a rule which clearly applied to the Israeli-Arab controversy" is undeniable. ${ }^{102}$ More than that, for in Mr. Dean's view, "it specifically determines the heated controversy between Israel and Arab states as to the right of Israeli shipping to pass through the Strait of Tiran to the Gulf of Aqaba."103

Obviously, the rule could not achieve this purpose if it depended upon ratification of Arab states involved in that controversy.

\footnotetext{
${ }^{\circ 0}$ Dean, The Geneva Conference on the Law of the Sea: What Was Accomplished, 52 AM. J. INT'L I. 607,623 (1958).

${ }^{100}$ Gross, supra note 9, at $587-89,592-94$.

${ }^{101}$ Letter from Arthur H. Dean to Leo Gross, Feb. 29, 1968.

${ }^{102}$ Dean, supro note 99 , at 623 .

${ }^{103}$ Id. at 621. (Emphasis added.) .
} 


\section{$\mathrm{V}$}

\section{Conclusions}

There is no need to summarize the results of this analysis of the controversy over the right of free and innocent passage through the Gulf. In the present submission none of the propositions advanced by the United Arab Republic and its supporters can be accepted as juridically persuasive: neither the claim that the Gulf of Aqaba has been from time immemorial an historic gulf, a discovery which at least on the juridical plane was made only in 1957, nor the claim that Israel's territory does not comprise a stretch of the coast of the Gulf, neither the existence of belligerent rights and of a continuing state of war, nor the claim that the Strait of Tiran is not an international waterway.

Apart from the specific issues relating to the conflict, there emerged in the 1958 Geneva Conference and in the 1967 debates in the Security Council and the General Assembly a concern for ensuring free and innocent passage through international waterways for all states. For if it is admitted that a coastal state is entitled to use waterways as an instrument of national policy no state would contemplate the future with equanimity. While many delegations addressed themselves, in the 1967 debates, to the concrete issue of innocent passage through the Suez Canal and the Strait of Tiran and in the Gulf of Aqaba, the delegate of Italy formulated the problem in comprehensive terms when he said:

There are, moreover, questions which affect the more general interests of the international community. I have in mind the problems of international waterways, the freedom of which is guaranteed by international law and is a matter of primary interest for the whole world and particularly for those countries which, like Italy, are separated from the oceans by canals and straits. ${ }^{104}$

The issue is of transcendent importance for the welfare of all nations, the developed and the developing ones.

At the 1958 Geneva Conference the proposal had already been made to include in article 16, paragraph 4, the words "straits or other sea-lanes," on the ground that "[ $t]$ he term 'straits' was much too narrow, because there were sea-lanes used for international navigation elsewhere than in straits." 105

\footnotetext{
${ }^{106}$ U.N. Doc. A/PV.1530, at 66 (1967). In this connection mention may be made of the statement of the British representative:

"In addition, there is one most urgent and most dangerous issue of all: the question of the right of passage for shipping of all nationalities through the Strait of Tiran. The maintenance of the provisions of the Geneva Convention on the Territorial Sea dealing with international navigation between the high seas and territorial waters is of the gravest concern to my Government, as it must be to all engaged in international trade."

U.N. Doc. S/PV.r342, at I8-20 (1967). See also statements by the delegations indicated in U.N. Docs. A/PV.1531, 22 June 1967, at 29-30 (Belgium); A/PV.1537, 27 June 1967, at 46 (Nigeria); A/PV.1541, 29 June 1967, at 13-15 (Peru); A/PV.r542, 29 June 1967, at 41 (Australia); and id. at 58-60 (Costa Rica).

${ }^{105}$ The words are those of the delegate of the Netherlands, U.N. Conf. on the Law of the Sea, Off. Rec., vol. III, Ist Comm. 94, U.N. Doc. A/Conf.13/39 (I958). See Gross, supra note 9, at 588.
} 
The inclusion of the word "sea-lanes" would have had the same justification as the deletion of the word "normally," that is, avoidance of technical controversies over meanings of "strait" or "canal" and concentration on the use as a highway for international navigation.

In view of this precedent and the concern for freedom of navigation on the high seas, it was probably no mere accident that the resolution of the Security Council adopted on November 22, 1967 , used the comprehensive term "international waterways" when it affirmed the necessity "[f]or guaranteeing freedom of navigation through international waterways in the area."106

It may also have been a matter of intent rather than mere choice of words that the resolution expresses the concern of the Security Council for guaranteeing freedom of navigation through international waterways "in the area." For while the conflict between Israel and its Arab neighbors in the past has related, insofar as freedom of navigation was involved, to the Suez Canal, the Strait of Tiran, and the Gulf of Aqaba, there are "in the area" other international waterways such as the Straits of Bab El Mandeb.

These straits have a vital function in the area for they "join the high seas of the Gulf of Aden to those of the Red Sea and form part of the international route from the Mediterranean to the Far East."107 Four states border on these Straits: Ethiopia and French Somaliland on the African side, and Yemen and the Republic of South Yemen, the former British Aden Protectorate, on the Arabian side. Perim Island itself was formerly part of the British Colony of Aden and has become part of the Republic of South Yemen.

As concerns freedom of passage through these straits, one would assume that in the contemplation of the United States they would be covered by article 16, paragraph 4 , of the $195^{8}$ Convention. This would follow from the traditional policy of the United States in favor of freedom of transit through international waterways including international straits.

Insofar as the United Kingdom and the new Republic of South Yemen are concerned, the following statement by the British Foreign Secretary, Mr. George Brown, in the House of Commons on November 29, 1967 may be quoted:

There is as yet no new Government, but the delegation from the NL.F., in the course of discussions in Geneva, as the communiqué shows, had agreed to accept

${ }^{100}$ S.C. Res. 242 ( 1967 ), supra note 73. It is worth noting that all three draft resolutions before the Council-a three-power (India, Mali, and Nigeria) draft, a United States draft and a Soviet Union draftemphasized in one way or another freedom of navigation or innocent passage. See 4 U.N. MoNrHLY Chron. 9 (Dec. 1967). The resolution which was unanimously adopted issued from a United Kingdom draft. Id. at 15,17 .

${ }^{107}$ Kennedy, A Brief Geographical and Hydrographical Study of Straits Which Constitute Routes for International Traffic, I United Nations Conference on the Law of the Sea, Official Records, U.N. Doc. A/Conf.r3/6, at II5 (1958). The length of the Straits is 50 miles, the Large Strait between Perim Island and the African coast is about $9^{1 / 4}$ miles wide, and the Small Strait between Perim Island and Arabia is about $I \frac{1}{2}$ miles wide. Id. 
the international obligations which we have extended to Aden, and one of those is the Geneva Convention which seeks to ensure free passage through international waterw2ys. One of these is the waterway of the Straits of Perim.108

The situation appears then to be adequately covered by the devolution or inheritance agreement between the United Kingdom and the Republic of South Yemen, although it is not clear from the statement whether the agreement is a formal one or sufficiently formal to be registered with the United Nations.

Conflict among nations has often contributed to the strengthening and revitalization of international law and organization. One has to remind himself of the major wars in the modern era which promoted the growth of law and organization: the Napoleonic Wars contributed through the Congress of Vienna to the development of international river law and gave birth to the Concert system; the First World War gave birth to the League of Nations and the Permanent Court of International Justice; the Second World War created the United Nations; the Indus River conflict between India and Pakistan contributed powerfully to the study and development of the law of river basins. Examples could be multiplied. Problem-solving has been a constructive experience for nations. It may then be legitimate to expect that the solution of the conflict in the Middle East will hasten the establishment of the law governing international waterways on a firm foundation by the application of the principle that such waterways shall not be used as an instrument of national policy but for the benefit of all nations. In the long run an increasingly interdependent world cannot settle for less.

${ }^{108}$ PARL. DEB., H.C. (5th ser.) 438 (1967). Concerning the politics of the area, see Klieman, Bab .1l-Mandab: The Red Sea in Transition, II ORBIS 758 (1967). 